\title{
Communication about genetic testing with breast and ovarian cancer patients: a scoping review
}

\author{
Chris Jacobs $\mathbb{D}^{1,2} \cdot$ Christine Patch ${ }^{3,4} \cdot$ Susan Michie $^{2}$
}

Received: 10 June 2018 / Revised: 4 October 2018 / Accepted: 7 November 2018 / Published online: 20 December 2018

(c) The Author(s) 2018. This article is published with open access

\begin{abstract}
Genetic testing of patients with cancer is increasingly offered to guide management, resulting in a growing need for oncology health professionals to communicate genetics information and facilitate informed decision-making in a short time frame. This scoping review aimed to map and synthesise what is known about health professionals' communication about genetic testing for hereditary breast and ovarian cancer with cancer patients. Four databases were systematically searched using a recognised scoping review method. Areas and types of research were mapped and a narrative synthesis of the findings was undertaken. Twenty-nine papers from 25 studies were included. Studies were identified about (i) information needs, (ii) process and content of genetic counselling, (iii) cognitive and emotional impact, including risk perception and recall, understanding and interpretation of genetic test results, and anxiety and distress, (iv) patients' experiences, (v) communication shortly after diagnosis and (vi) alternatives to face-to-face genetic counselling. Patients' need for cancerfocused, personalised information is not always met by genetic counselling. Genetic counselling tends to focus on biomedical information at the expense of psychological support. For most patients, knowledge is increased and anxiety is not raised by pre-test communication. However, some patients experience anxiety and distress when results are disclosed, particularly those tested shortly after diagnosis who are unprepared or unsupported. For many patients, pre-test communication by methods other than face-to-face genetic counselling is acceptable. Research is needed to identify patients who may benefit from genetic counselling and support and to investigate communication about hereditary breast and ovarian cancer by oncology health professionals.
\end{abstract}

\section{Introducton}

The increase in genetic testing shortly after diagnosis to guide breast and ovarian cancer management requires a shift in pre-test genetic communication, from specialist genetics to mainstream oncology services. Oncology health

Chris Jacobs

chris.jacobs@uts.edu.au

1 Graduate School of Health, University of Technology Sydney, PO Box 123, Broadway, NSW 2007, Australia

2 Department of Clinical, Education and Health Psychology, University College London, 1-19 Torrington Place, London WC1E 7HB, UK

3 Florence Nightingale Faculty, Nursing, Midwifery and Palliative Care, King's College London, 57 Waterloo Road, London SE1 8WA, UK

4 Genomics England, Queen Mary University of London, Dawson Hall, London EC1M 6BQ, UK professionals are increasingly required to discuss the options and possible outcomes of genetic testing with patients. Alongside this change, genetics health professionals are required to counsel cancer patients who are newly diagnosed or receiving palliative care about the implications of a genetic test result for themselves and their families. Learning from previous practice and research can help to inform the development of new approaches to communicating about genetic testing with cancer patients.

This scoping review aimed to summarise and map the range, extent and nature of the published research into communication about hereditary breast and ovarian cancer between genetics and oncology health professionals and patients. The purpose of the review was to summarise and disseminate the research findings for health professionals, policy makers and consumers and inform future clinical practice and research as the shift in genetic testing takes place.

Two previous reviews investigating studies into the process and content of genetic counselling concluded that 
Table 1 Inclusion and exclusion criteria used for screening articles

\begin{tabular}{|c|c|c|}
\hline & Included & Excluded \\
\hline Population & $\begin{array}{l}\text { - Women with a personal history of breast or ovarian cancer } \\
\text { - Health professionals specialising in genetics or oncology, including genetic } \\
\text { counsellors, geneticists, oncologists, surgeons and nurses }\end{array}$ & $\begin{array}{l}\text { - Men with breast/prostate cancer } \\
\text { - Cancers other than breast or ovarian cancer } \\
\text { - Children } \\
\text { - Individuals at risk }\end{array}$ \\
\hline Concept & $\begin{array}{l}\text { - Communication about genetic testing and/or hereditary cancer management } \\
\text { - Process and/or content of verbal or written communication, the information } \\
\text { needed, knowledge understood and recalled or the experience of this } \\
\text { communication } \\
\text { - Participants, contexts, interventions or strategies involving patients, health } \\
\text { professionals, health conditions or communication methods }\end{array}$ & $\begin{array}{l}\text { - Impact of genetic test results } \\
\text { - Studies where findings for cancer patients were not } \\
\text { presented separately from at-risk women } \\
\text { - Family communication }\end{array}$ \\
\hline Context & $\begin{array}{l}\text { - Qualitative and quantitative original research articles of all designs } \\
\text { published in English } \\
\text { - Genetics or oncology setting } \\
\text { - Communication after completing, prior to or during cancer treatment } \\
\text { - Expected outcomes from literature about at-risk women: } \\
\text { ○ Ratio of health professional-patient talk } \\
\text { ○ Accuracy and extent of knowledge/recall } \\
\text { ○ Met/unmet communication needs } \\
\text { ○ Satisfaction } \\
\text { ○ Distress/anxiety } \\
\text { ○ Intention to have a procedure/investigation, for example, genetic testing/ } \\
\text { surgery } \\
\text { o Experience/understanding } \\
\text { - Communication methods }\end{array}$ & $\begin{array}{l}\text { - Reviews, editorials, chapters and commentaries } \\
\text { - Primary/palliative care setting }\end{array}$ \\
\hline
\end{tabular}

genetic counselling is often provider-driven, educational and biomedical in content with little attention to psychosocial aspects $[1,2]$. These two reviews addressed communication about all types of hereditary conditions, including women with and at risk of hereditary breast and ovarian cancer.

A review of the communication goals and needs of cancer patients identified unmet communication needs and concluded that communication outcomes are enhanced when health professionals attend to patients' emotional needs [3]. Systematic reviews have highlighted the influence of health professionals' personal characteristics on the effectiveness of communication with cancer patients [4, 5], the need for an individualised approach [6] and the importance of good communication skills [7].

No previous systematic or scoping reviews of communication about genetic testing or hereditary cancer management with breast and ovarian cancer patients were identified.

\section{Methods}

\section{Scoping review methodology}

This scoping review was informed by the methodology developed by key authors in the field [8-10]. The procedure was based on the most recent guidance for conducting scoping reviews $[10,11]$.

\section{Review question}

The review question was driven by the population, concept and context of the review [11]: What is known about the communication that takes place about hereditary cancer between genetics or oncology health professionals and patients with breast or ovarian cancer?

\section{Search strategy}

A search of MEDLINE, CINAHL, PsycINFO and EMBASE databases was undertaken for the following search terms adapted for each database: genetic counselling or genetic counseling or genetic testing and ovarian, breast or fallopian tube neoplasms or neoplastic syndromes, hereditary syndromes or hereditary breast and ovarian cancer syndrome or BRCA1 or BRCA2. The databases were searched for studies published between 1994, when the BRCA1 gene was identified, and October 2017. Forward and backwards citation searches were undertaken on the Web of Science and Scopus for included papers.

\section{Article selection}

The inclusion and exclusion criteria used for screening the articles were based on the population, concept and context of the research question [10, 11] (Table 1). Titles and abstracts were screened by two independent researchers (CJ 
and CP) until a good level of agreement was reached (97\%). Remaining articles were reviewed by $\mathrm{CJ}$ and validated by CP.

\section{Data extraction}

Details of the method, participants, sample size and interventions and outcomes significant to the review question were documented onto a data extraction tool [11] by CJ. In accordance with scoping review methodology [8], quality assessment of selected studies was not undertaken.

\section{Data synthesis}

The iterative process of data synthesis involved a preliminary synthesis of the study findings, exploration of relationships between the studies and summary of the synthesised findings in narrative form within the areas of study $[12,13]$. To identify themes and develop a preliminary synthesis of the findings, the studies were organised according to the main area of study followed by identification of relationships between the studies.

\section{Results}

\section{Overview of included studies}

The PRISMA flow diagram [14] shows the number of studies identified, included and excluded (Fig. 1). No studies of cancer patients were identified prior to 2000. Since 2008, more studies have focused on cancer patients only than on cancer patients and at-risk women combined. Health professionals were mainly genetic counsellors or clinical geneticists, although one study included the views of oncology health professionals. The included studies were published between 2000 and 2017 and were from the Australia, North America, Europe and Scandinavia. Most of the studies involved surveys. The types of participants, country of origin of the research and qualitative or quantitative research methods for the selected studies are shown in Table 2. Six areas of research were identified. Most studies investigated the cognitive and emotional impact of genetic counselling and testing. The research areas investigated by the selected studies are shown in Table 3. Details of the included studies are shown in Table 4.

\section{Areas of research}

\section{Patients' information needs}

Five articles were identified that addressed the information needs of cancer patients about hereditary cancer [15-19].

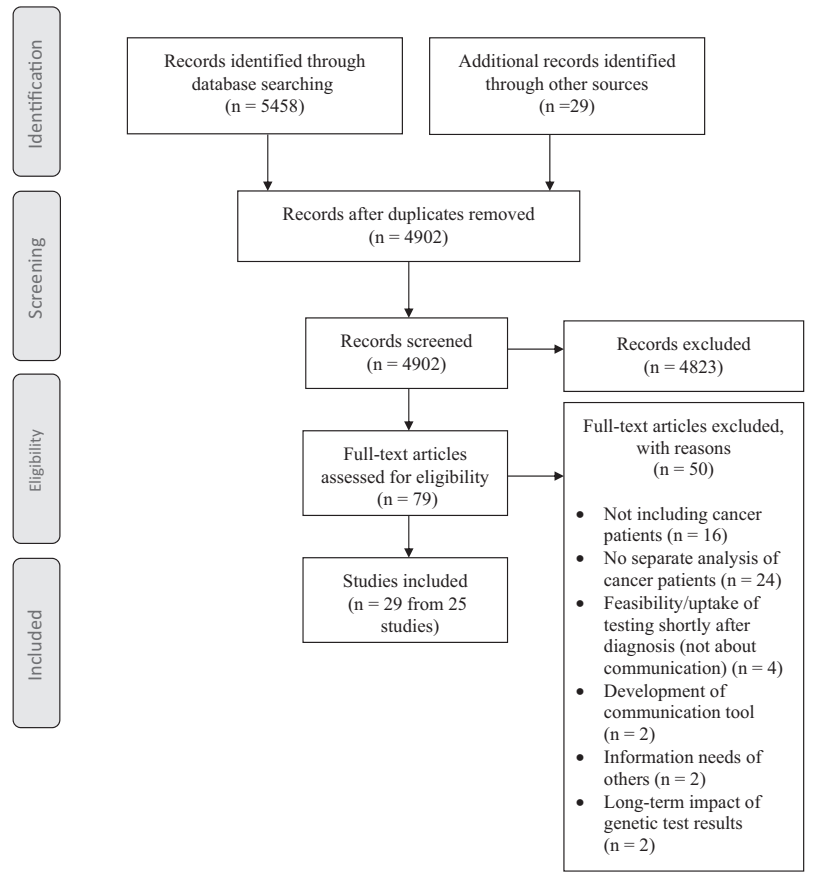

Fig. 1 PRISMA flow diagram

One study found that following pre-test genetic counselling, cancer patients $(n=69)$ reported unmet information needs about their risk of contralateral breast cancer and the cancer risks for their relatives [15]. Prior to counselling, $77 \%$ of the patients wanted information about their own risk and $98 \%$ wanted information about their relatives' risk. This information was discussed in $<45 \%$ of the consultations [15].

A survey of cancer patients $(n=46)$ and at-risk women $(n=33)$ found that cancer patients reported more unmet information needs about treatment options, including surgery, screening and chemoprevention [16]. Two qualitative studies, one with 26 breast cancer patients [18] and one with 22 ovarian cancer patients [17] investigated the actual and hypothetical information needs of those tested shortly after diagnosis. The studies identified a preference for brief, personalised, positive and straightforward information without statistics. Most patients considered it important to have information about the purpose of testing, the implications for treatment decisions, the time frame for results and the availability of predictive testing for relatives [17, 18]. A Delphi survey of 16 expert genetics and cancer health professionals and 16 service users with cancer and a BRCA1/BRCA2 pathogenic variant agreed that information about inheritance, genetic testing, cancer risks and the management of hereditary cancer were key messages for cancer patients. The implications of genetic testing for treatment were not considered to be key messages [19]. 
Table 2 Types of participants, including patients and health professionals (HP), country/continent of research origin and qualitative/quantitative research methods in selected studies

\begin{tabular}{|c|c|c|c|c|c|c|c|c|c|c|}
\hline \multirow{2}{*}{$\begin{array}{l}\text { References in ascending } \\
\text { order according to year of } \\
\text { publication—author [ref.] }\end{array}$} & \multicolumn{4}{|l|}{ Participants } & \multicolumn{4}{|c|}{ Country/continent } & \multicolumn{2}{|c|}{ Methods } \\
\hline & $\begin{array}{l}\text { Cancer } \\
\text { patients and } \\
\text { at-risk } \\
\text { women }\end{array}$ & $\begin{array}{l}\text { Cancer } \\
\text { patients } \\
\text { only }\end{array}$ & $\begin{array}{l}\text { Genetics } \\
\text { HPs }\end{array}$ & $\begin{array}{l}\text { Oncology } \\
\text { HPs }\end{array}$ & $\begin{array}{l}\text { Europe/ } \\
\text { Scandinavia }\end{array}$ & UK & Australia & $\begin{array}{l}\text { North } \\
\text { America }\end{array}$ & Qual. & Quant. \\
\hline Metcalfe et al. [16] & $\mathrm{X}$ & & & & & & & $\mathrm{X}$ & & $\mathrm{X}$ \\
\hline Randall et al. [23] & & $\mathrm{X}$ & & & & & $\mathrm{X}$ & & & $\mathrm{X}$ \\
\hline Hallowell et al. [35] & & $\mathrm{X}$ & & & & $\mathrm{X}$ & & & $\mathrm{X}$ & \\
\hline Lobb et al. $[21]^{\mathrm{a}}$ & $\mathrm{X}$ & & $\mathrm{X}$ & & & & $\mathrm{X}$ & & & $\mathrm{X}$ \\
\hline Butow and Lobb $[20]^{\mathrm{a}}$ & $\mathrm{X}$ & & $\mathrm{X}$ & & & & $\mathrm{X}$ & & & $\mathrm{X}$ \\
\hline Lobb et al. $[15]^{\mathrm{a}}$ & $\mathrm{X}$ & & $\mathrm{X}$ & & & & $\mathrm{X}$ & & & $\mathrm{x}$ \\
\hline van Dijk et al. [36] & $\mathrm{X}$ & & & & $\mathrm{X}$ & & & & & $\mathrm{X}$ \\
\hline van Roosmalen et al. [39] & $\mathrm{X}$ & & & & $\mathrm{X}$ & & & & & $\mathrm{X}$ \\
\hline Mancini et al. [31] & & $\mathrm{X}$ & & & $\mathrm{x}$ & & & & & $\mathrm{x}$ \\
\hline Pieterse et al. [22] & $\mathrm{X}$ & & $\mathrm{X}$ & & $\mathrm{X}$ & & & & & $\mathrm{X}$ \\
\hline Maheu and Thorne [34] & & $\mathrm{X}$ & & & & & & $\mathrm{X}$ & $\mathrm{X}$ & \\
\hline Vadaparampil et al. [38] & & $\mathrm{X}$ & & & & & & $\mathrm{X}$ & $\mathrm{X}$ & \\
\hline Vos et al. [37] & & $\mathrm{X}$ & & & $\mathrm{x}$ & & & & $\mathrm{X}$ & \\
\hline Pieterse et al. [40] & $\mathrm{X}$ & & $\mathrm{X}$ & & $\mathrm{x}$ & & & & & $\mathrm{X}$ \\
\hline Vadaparampil et al. [42] & & $\mathrm{X}$ & & & & & & $\mathrm{X}$ & & $\mathrm{X}$ \\
\hline Vos et al. $[24]^{\mathrm{b}}$ & & $\mathrm{X}$ & & & $\mathrm{x}$ & & & & & $\mathrm{X}$ \\
\hline Christie et al. [27] & & $\mathrm{X}$ & & & & & & $\mathrm{X}$ & & $\mathrm{X}$ \\
\hline Meiser et al. [18] & & $\mathrm{X}$ & & & & & $\mathrm{x}$ & & $\mathrm{X}$ & \\
\hline Vos et al. $[25]^{\mathrm{b}}$ & & $\mathrm{X}$ & & & $\mathrm{X}$ & & & & & $\mathrm{X}$ \\
\hline Vos et al. $[26]^{\mathrm{b}}$ & & $\mathrm{X}$ & & & $\mathrm{x}$ & & & & & $\mathrm{X}$ \\
\hline Gleeson et al. [17] & & $\mathrm{X}$ & & & & & $\mathrm{X}$ & & $\mathrm{X}$ & \\
\hline Sie et al. [43] & & $\mathrm{X}$ & & & $\mathrm{x}$ & & & & & $\mathrm{X}$ \\
\hline Jacobs et al. [33] & $\mathrm{X}$ & & & & & $\mathrm{X}$ & & & & $\mathrm{X}$ \\
\hline Scherr et al. [29] & & $\mathrm{X}$ & & & & & & $\mathrm{x}$ & & $\mathrm{X}$ \\
\hline Quinn et al. [32] & & $\mathrm{X}$ & & & & & $\mathrm{X}$ & & & $\mathrm{X}$ \\
\hline Augestad et al. [41] & & $\mathrm{X}$ & & & $\mathrm{X}$ & & & & $\mathrm{X}$ & \\
\hline Benusiglio et al. [30] & & $\mathrm{X}$ & & & $\mathrm{X}$ & & & & & $\mathrm{X}$ \\
\hline Bredart et al. [28] & & $\mathrm{X}$ & & & $\mathrm{x}$ & & & & & $\mathrm{X}$ \\
\hline Jacobs et al. [19] & & $\mathrm{X}$ & $\mathrm{X}$ & $\mathrm{X}$ & & $\mathrm{X}$ & & & & $\mathrm{X}$ \\
\hline
\end{tabular}

${ }^{a}$ Papers from the same Australian study

${ }^{\mathrm{b}}$ Papers from the same Netherlands study

\section{Process and content of genetic counselling}

Four articles from two studies addressed the process and content of genetic counselling communication [15, 20-22]. One of these studies [15, 20,21] involved a content analysis of genetic counselling consultations with patients $(n=69)$ and at-risk women $(n=89)$ and seven genetics health professionals. Essential information about hereditary breast cancer was consistently communicated during pre-test counselling. Emotional concerns were not however always identified and genetics health professionals infrequently facilitated patients' involvement in consultations [20]. The percentage of consultations in which specific cancer risks were discussed was similar for the cancer patients and the at-risk women [20]. Health professionals discussed significantly more aspects of genetic testing $(p<.001)$, facilitated active patient involvement $(p<.001)$ and used more supportive and counselling behaviours with cancer patients than with at-risk women $(p=.02)$ [21]. Despite supportive counselling, $68 \%$ of the cancer patients studied did not feel 
Table 3 Areas of research

\begin{tabular}{|c|c|c|c|c|c|c|c|c|}
\hline \multirow{2}{*}{$\begin{array}{l}\text { References in } \\
\text { ascending order } \\
\text { according to year of } \\
\text { publication-author } \\
\text { [ref.] }\end{array}$} & \multirow{2}{*}{$\begin{array}{l}\text { Information } \\
\text { needs }\end{array}$} & \multirow{2}{*}{$\begin{array}{l}\text { Process } \\
\text { and } \\
\text { content }\end{array}$} & \multicolumn{3}{|c|}{ Cognitive and emotional impact } & \multirow[t]{2}{*}{ Experience } & \multirow{2}{*}{$\begin{array}{l}\text { Timing of pre-test } \\
\text { communication }\end{array}$} & \multirow{2}{*}{$\begin{array}{l}\text { Alternatives to } \\
\text { face-to-face } \\
\text { genetic } \\
\text { counselling }\end{array}$} \\
\hline & & & $\begin{array}{l}\text { Recall and } \\
\text { risk } \\
\text { perception }\end{array}$ & $\begin{array}{l}\text { Understand } \\
\text { and interpret }\end{array}$ & $\begin{array}{l}\text { Anxiety } \\
\text { and } \\
\text { distress }\end{array}$ & & & \\
\hline Metcalfe et al. [16] & $\mathrm{X}$ & & & & & & & \\
\hline Randall et al. [23] & & & $\mathrm{X}$ & & $\mathrm{X}$ & & & \\
\hline Hallowell et al. [35] & & & & $\mathrm{X}$ & & $\mathrm{X}$ & & \\
\hline Lobb et al. $[21]^{\mathrm{a}}$ & & $\mathrm{X}$ & & & & & & \\
\hline Butow and Lobb $[20]^{a}$ & & $\mathrm{X}$ & & & & & & \\
\hline Lobb et al. $[15]^{\mathrm{a}}$ & $\mathrm{X}$ & $\mathrm{X}$ & & & & & & \\
\hline van Dijk et al. [36] & & & & $\mathrm{X}$ & $\mathrm{X}$ & & & \\
\hline $\begin{array}{l}\text { van Roosmalen et al. } \\
\text { [39] }\end{array}$ & & & & & $\mathrm{X}$ & & & \\
\hline Mancini et al. [31] & & & $\mathrm{X}$ & & $\mathrm{X}$ & & & $\mathrm{X}$ \\
\hline Pieterse et al. [22] & & $\mathrm{X}$ & & & & & & \\
\hline $\begin{array}{l}\text { Maheu and Thorne } \\
\text { [34] }\end{array}$ & & & & $\mathrm{X}$ & & $\mathrm{X}$ & & \\
\hline $\begin{array}{l}\text { Vadaparampil et al. } \\
\text { [38] }\end{array}$ & & & & $\mathrm{X}$ & & & $\mathrm{X}$ & \\
\hline Vos et al. [37] & & & & $\mathrm{X}$ & & $\mathrm{X}$ & & \\
\hline Pieterse et al. [40] & & & & & $X$ & & & \\
\hline $\begin{array}{l}\text { Vadaparampil et al. } \\
\text { [42] }\end{array}$ & & & & & & & $\mathrm{X}$ & \\
\hline Vos et al. $[24]^{\mathrm{b}}$ & & & $\mathrm{X}$ & & & & & \\
\hline Christie et al. [27] & & & $\mathrm{X}$ & & $\mathrm{X}$ & & $\mathrm{X}$ & \\
\hline Meiser et al. [18] & $\mathrm{X}$ & & & & & & $\mathrm{X}$ & \\
\hline Vos et al. $[25]^{\mathrm{b}}$ & & & $\mathrm{X}$ & $\mathrm{X}$ & & & & \\
\hline Vos et al. $[26]^{b}$ & & & $\mathrm{X}$ & & & & & \\
\hline Gleeson et al. [17] & $X$ & & & & & & $X$ & \\
\hline Sie et al. [43] & & & & & & & $X$ & $\mathrm{X}$ \\
\hline Jacobs et al. [33] & & & $\mathrm{X}$ & & & & & \\
\hline Scherr et al. [29] & & & $\mathrm{X}$ & & & & $\mathrm{X}$ & \\
\hline Quinn et al. [32] & & & $\mathrm{X}$ & & $\mathrm{X}$ & & $\mathrm{X}$ & $\mathrm{X}$ \\
\hline Augestad et al. [41] & & & & & & $\mathrm{X}$ & $\mathrm{X}$ & $\mathrm{X}$ \\
\hline Benusiglio et al. [30] & & & $\mathrm{X}$ & & $\mathrm{X}$ & & $\mathrm{X}$ & $\mathrm{X}$ \\
\hline Bredart et al. [28] & & & $\mathrm{X}$ & & $X$ & & & \\
\hline Jacobs et al. [19] & $\mathrm{X}$ & & & & & & & \\
\hline
\end{tabular}

${ }^{a}$ Papers from the same Australian study

${ }^{\mathrm{b}}$ Papers from the same Netherlands study

reassured and 57\% felt they could have been helped to cope better with their situation [15].

The same study also identified that the risk of a pathogenic variant was communicated in $13.3 \%$ of consultations with cancer patients undergoing diagnostic testing. With atrisk women, some of whom were undergoing predictive testing, the risk of a pathogenic variant was communicated in $71.8 \%$ of consultations [15]. With the cancer patients, the risk of further cancers in the presence of a pathogenic variant was discussed in $37.3 \%$ of consultations and the risk of further cancers in the absence of a pathogenic variant was discussed in $29.3 \%$ of consultations [20]. Information about their own and their relatives' risks of cancer was communicated in $<45 \%$ of consultations [15]. In a separate study involving a survey and analysis of transcripts of pretest genetic counselling with 34 cancer patients and 17 at- 


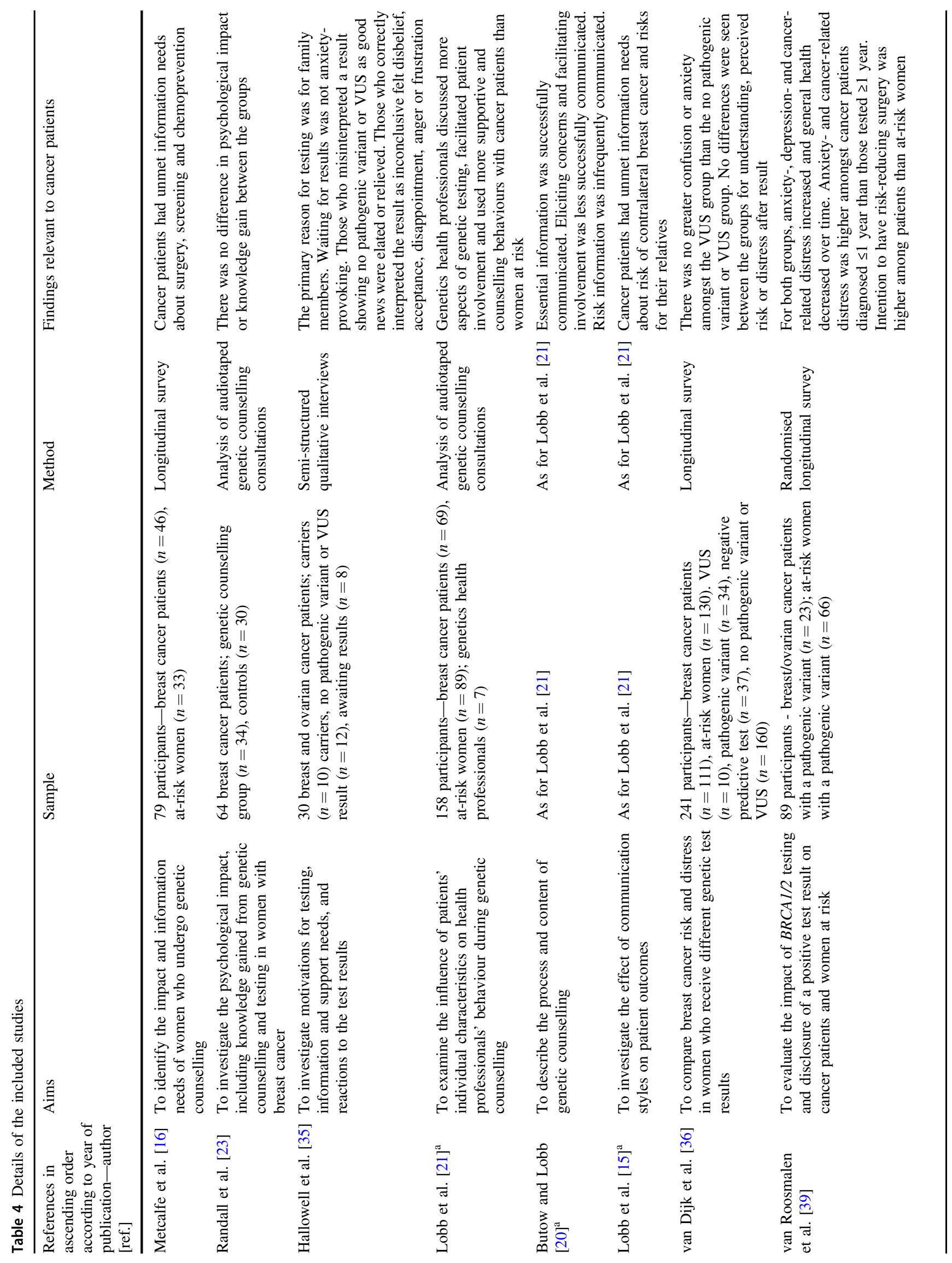




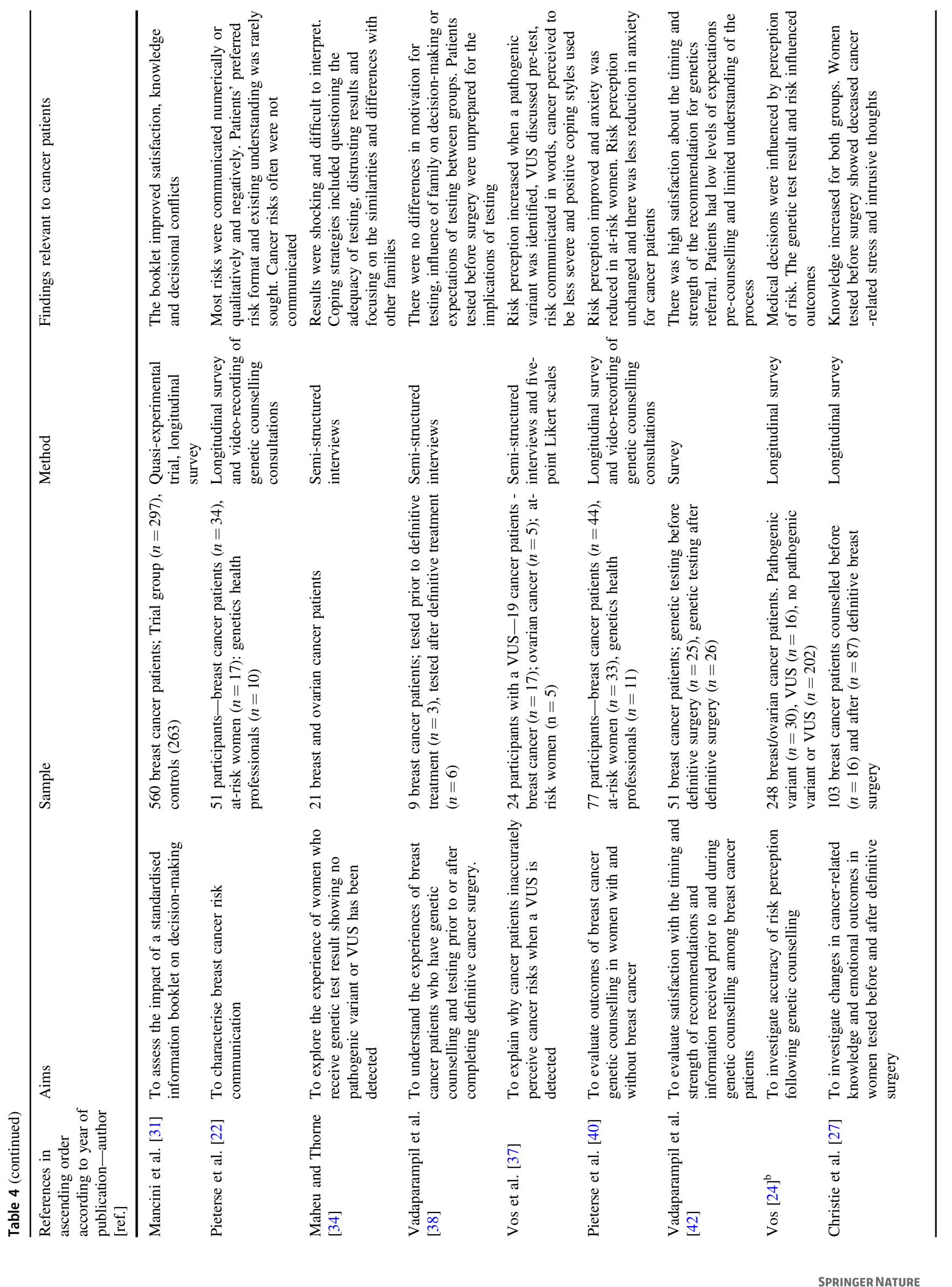




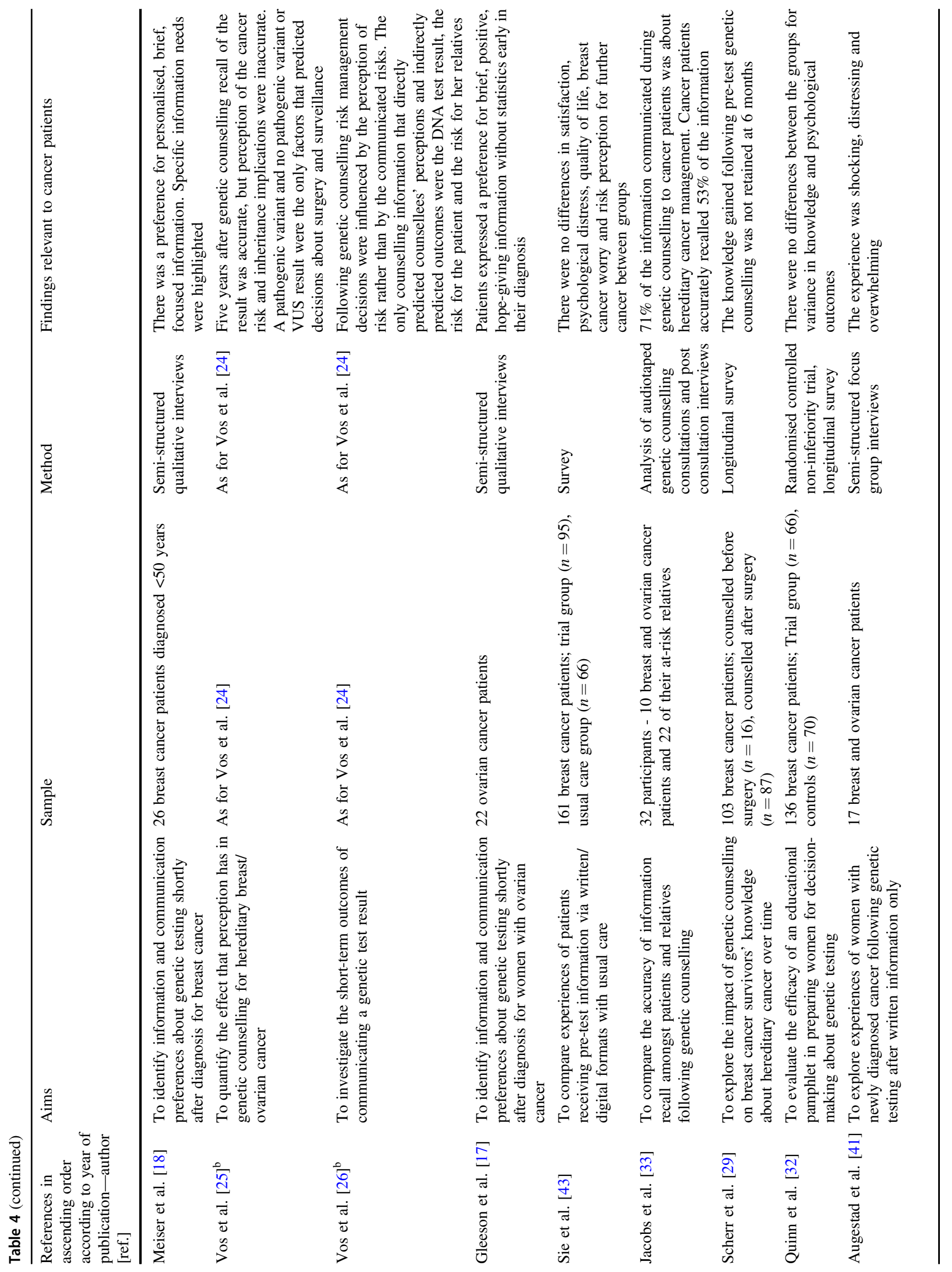




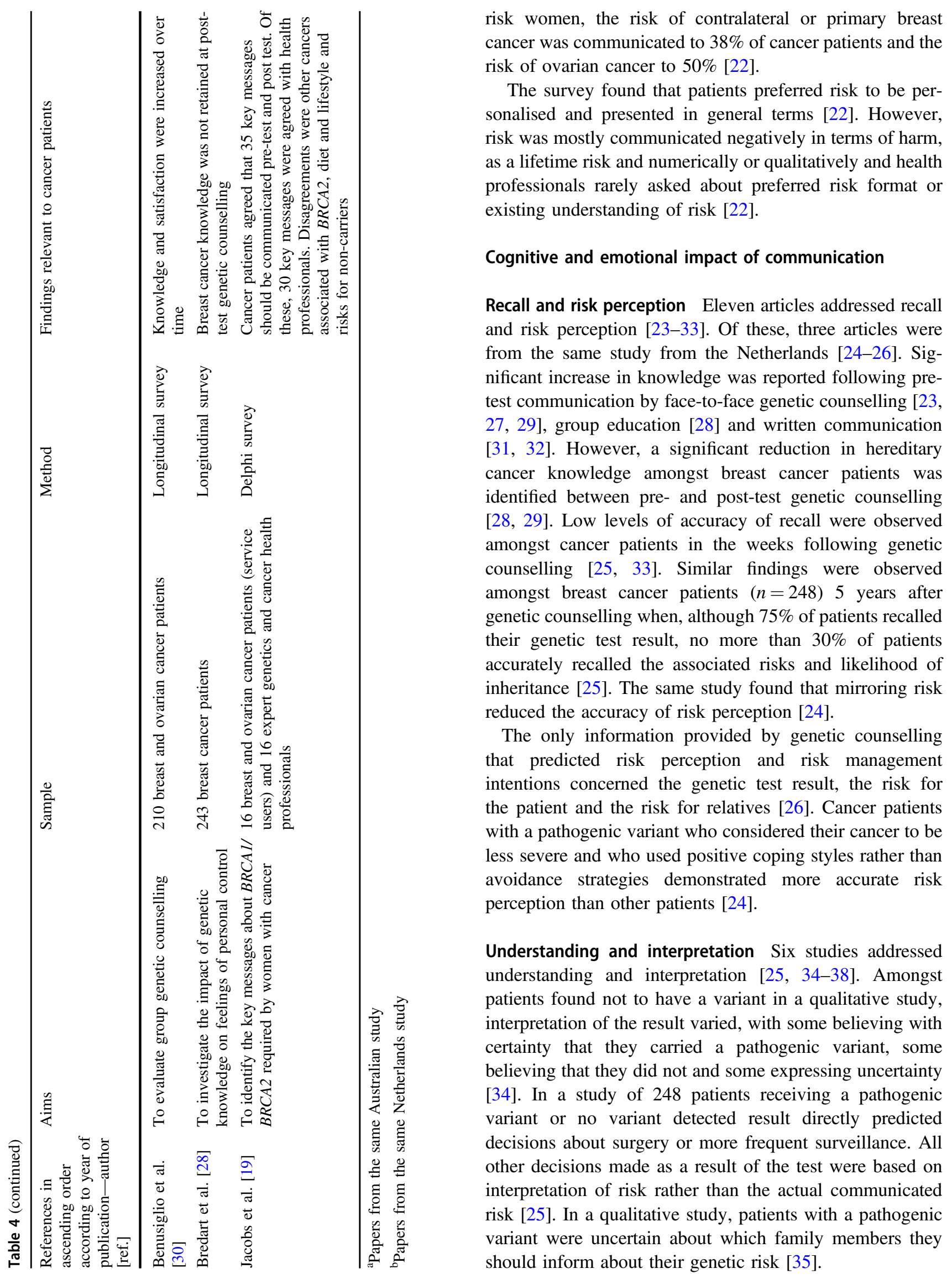


A longitudinal survey found no difference in reported understanding of the result or perceived breast cancer risk between cancer patients who received a variant of uncertain significance (VUS) $(n=10)$ and those who did not have a variant $(n=37)$ [36]. In a further qualitative study of 17 patients with a VUS, $77 \%$ interpreted the result as pathogenic, despite factual recall of the result as not informative. Of these, $50 \%$ underwent risk-reducing surgery in the year following the result [37]. A qualitative study of 30 breast and ovarian cancer patients found that those who misinterpreted a VUS result as good news experienced elation or relief, whereas those who correctly understood the result as inconclusive experienced a range of emotions, including disbelief, acceptance, disappointment, anger or frustration [35]. Patients who adopted more positive coping styles had a better understanding of the risks associated with a VUS [37].

A qualitative study of breast cancer patients interviewed following pre-test genetic counselling prior to or after definitive surgery found a lack of understanding about what would be involved and misunderstanding about the inevitability of genetic testing. Patients were unaware even after genetic counselling of the utility of genetic testing and surprised that testing might result in further surgery and heightened emotions [38].

Anxiety and distress Nine studies addressed anxiety and distress [23, 27, 28, 30-32, 36, 39, 40]. Pre-test communication did not have a negative impact on cancer-related distress, anxiety or depression, intrusive thoughts, decisional conflict, family involvement in decision-making or satisfaction amongst cancer patients in five of these studies [23, 27, 30-32]. However, three studies found that anxiety, depression and cancer-related distress were increased and general health decreased amongst cancer patients and at-risk women after disclosure of the genetic test result [28, 39, 40]. A longitudinal survey of 243 breast cancer patients found that amongst those who over-estimated their risk of a pathogenic variant at pre-test counselling, anxiety was raised at post-test counselling [28]. A randomised longitudinal survey found that cancer-related distress and anxiety was higher amongst patients diagnosed within a year of genetic testing than those tested over a year from diagnosis $(p=.05)$ [39]. In a survey of breast cancer patients, no differences were found in anxiety or psychological distress between those who received a VUS and those who in whom no variant was detected [36].

\section{Patients' experiences of communication}

Four qualitative studies addressed patients' experiences of communication [34, 35, 37, 41]. Three studies found that some patients tested after completing cancer treatment experienced confusion and shock upon receiving genetic test results [34, 35, 37]. A study of patients tested shortly after diagnosis without pre-test genetic counselling found that the emotional turmoil of the cancer diagnosis was heightened by the difficulty of receiving and comprehending the information [41]. Patients who were distressed by genetic test results that showed no variant was detected coped by questioning the adequacy of testing, distrusting the result and emphasising the difference between their family history and other higher risk families [34].

\section{Timing of pre-test communication}

Ten studies addressed the timing of pre-test communication [17, 18, 27, 29, 30, 32, 38, 41-43]. Pre-test communication shortly after diagnosis was acceptable to most patients studied and did not cause distress [17, 18, 27, 29, 30, 32, $42,43]$. Some patients were unprepared for the implications of testing or did not understand the utility of the test [38, 42]. A qualitative study of 17 breast and ovarian cancer patients tested shortly after diagnosis without prior genetic counselling found that patients experienced shock, distress and confusion [41].

\section{Alternatives to face-to-face genetic counselling}

Five studies addressed alternatives to face-to-face genetic counselling [30-32, 41, 43]. Knowledge and satisfaction were increased amongst patients who received pre-test communication via group education [30] or written information which aimed to supplement $[30,31]$ or replace genetic counselling [32]. Amongst 161 breast cancer patients who underwent genetic testing following written and digital communication without face-to-face genetic counselling, satisfaction with the amount and quality of pretest information was high with most stating they would choose the same approach again and would recommend the approach to other patients [44]. No differences were found in psychological distress, quality of life or risk perception amongst patients who did and did not receive face-to-face pre-test genetic counselling [44]. A qualitative study with a small sample of these same patients however highlighted the need for support and counselling to increase understanding and empower decision-making [41].

\section{Discussion}

Prior to 2008, most studies of communication about genetic testing for hereditary breast and ovarian cancer focused on at-risk women. Later studies of communication with cancer patients have mainly addressed genetic testing shortly after diagnosis. Although many studies have focused on the 
cognitive and emotional impact of genetic counselling, few have investigated patients' information needs, the process and content of the communication or patients' experiences of communication. Despite the increasing need to deliver genetic testing within mainstream oncology, all but one of the studies identified by this review involved genetics health professionals only and all addressed communication in the clinical genetics setting.

Although cancer patients expressed a need for simple, cancer-focused, personalised information, the information communicated about genetic testing is frequently difficult to understand [45] and does not always meet the needs of patients. For patients with cancer, information is often regarded as a method of reducing uncertainty and providing a sense of personal control as well as enabling informed decisions about treatment options [46, 47].

Genetic counselling of cancer patients focused on biomedical information-giving with less attention to psychological aspects. Studies of the process and content of genetic counselling with at-risk women have identified a similar focus [2, 45, 48-52]. In studies of communication by oncology health professionals with cancer patients, an individualised approach [6] and good communication skills [7] have been identified as requirements for effective communication.

Pre-test genetic counselling increased knowledge without raising anxiety or cancer-related distress. Similar findings have been observed following genetic counselling about hereditary breast and ovarian cancer with at-risk individuals $[53,54]$. Amongst cancer patients, genetic counselling did not influence risk perception. In contrast, systematic reviews have concluded that genetic counselling improves risk perception in individuals at risk of breast cancer [2, 55] and other genetic conditions [56].

Genetic test results were misunderstood or misinterpreted, leading some patients to make inappropriate decisions about surgery and hindering family communication. Previous studies found that women with cancer understand their genetic risk in the context of their previous cancer experience [57] and identified lack of understanding of the risks and benefits of genetic information as a barrier to family communication [58, 59]. Amongst patients with a VUS, there were conflicting findings with some patients perceiving no difference in cancer risk and others perceiving the result to be a pathogenic variant. A lack of clear understanding about the meaning of a VUS has also been identified amongst breast cancer specialists [60].

There was an increase in anxiety, depression and cancerrelated distress following results disclosure, especially amongst those who over-estimated their risk at pre-test genetic counselling and those tested without face-to-face genetic counselling. Increased cancer-related distress has also been observed in studies of the psychological impact of genetic testing amongst breast cancer patients following results disclosure [52, 57].

The few studies that investigated cancer patients' experiences of communication found that for patients who were unprepared, unsupported or tested shortly after diagnosis without pre-test genetic counselling, the results disclosure was shocking, confusing and distressing. The impact of lack of support on experiences of genetic counselling has been highlighted for patients with and at risk of cancer [61, 62].

Communication about genetic testing shortly after diagnosis was acceptable for most patients. Early studies found high anxiety amongst women tested within 1 year of breast cancer diagnosis [63] and concern amongst health professionals and patients about the timing of testing [64]. However, studies investigating actual and hypothetical experiences of genetic testing shortly after diagnosis have found that, for the most part, patients and health professionals consider this type of genetic testing to be acceptable and desirable for decision-making if treatment options are improved as a result $[65,66]$.

For many cancer patients, pre-test communication without individual face-to-face genetic counselling may be acceptable, although this review identified that some patients need enhanced support and counselling. Other studies have found no differences in knowledge, distress or satisfaction amongst patients who have received genetics communication within the clinical genetics setting via group education [67] or video-conferencing [68].

This scoping review maps the current range of evidence specific to health professionals' communication about hereditary cancer with cancer patients. This review should not be considered a definitive review of the literature in this field as, consistent with the methodology, no quality assessment was made. Due to the breadth of the studies reviewed, some areas of research only include a few studies. It is only possible to draw tentative conclusions about the clinical implications from these findings.

The findings suggest that greater attention may be needed to the psychological and supportive aspects of genetic counselling for cancer patients. If pre-test communication is increasingly to be provided via methods other than face-toface genetic counselling, the post-test genetic counselling appointment may be the only opportunity for cancer patients to interact with a genetics health professional. Helping patients and families to adjust to a genetic diagnosis and facilitating dissemination of genetics information within families will become increasingly important aspects of the role of genetics health professionals. Patients with a pathogenic variant and those with a VUS may need additional help to understand the implications of genetic test results and support with decision-making about cancer management and cancer risk management. The limited 
studies of experiences of communication suggest that some patients may need enhanced counselling and support throughout the genetic testing process. As genetic testing becomes further integrated into mainstream oncology, it will be increasingly important to investigate communication about genetic testing by oncology health professionals and to develop and evaluate new models of communicating about genetic testing with cancer patients.

\section{Disclaimer}

This article presents independent research funded by the NIHR. The views expressed are those of the authors and not necessarily those of the NHS, the NIHR or the Department of Health.

Acknowledgements This study was funded by a National Institute for Health Research (NIHR) Doctoral Research Fellowship award (DRF/ 2010/03/067) awarded to C J.

\section{Compliance with ethical standards}

Conflict of interest The authors declare that they have no conflict of interest.

Open Access This article is licensed under a Creative Commons Attribution 4.0 International License, which permits use, sharing, adaptation, distribution and reproduction in any medium or format, as long as you give appropriate credit to the original author(s) and the source, provide a link to the Creative Commons license, and indicate if changes were made. The images or other third party material in this article are included in the article's Creative Commons license, unless indicated otherwise in a credit line to the material. If material is not included in the article's Creative Commons license and your intended use is not permitted by statutory regulation or exceeds the permitted use, you will need to obtain permission directly from the copyright holder. To view a copy of this license, visit http://creativecommons. org/licenses/by/4.0/.

\section{References}

1. Paul J, Metcalfe S, Stirling L, Wilson B, Hodgson J. Analyzing communication in genetic consultations-a systematic review. Patient Educ Couns. 2015;98:15-33.

2. Meiser B, Irle J, Lobb E, Barlow-Stewart K. Assessment of the content and process of genetic counseling: a critical review of empirical studies. J Genet Couns. 2008;17:434.

3. Hack TF, Degner LF, Parker PA. The communication goals and needs of cancer patients: a review. Psychooncology. 2005; 14:831-45.

4. Tay LH, Hegney DG, DNurs EA. A systematic review on the factors affecting effective communication between registered nurses and oncology adult patients in an inpatient setting. JBI Libr Syst Rev. 2010;8:869-916.

5. De Vries AM, de Roten Y, Meystre C, Passchier J, Despland JN, Stiefel F. Clinician characteristics, communication, and patient outcome in oncology: a systematic review. Psychooncology. 2014;23:375-81.
6. Rodin G, Mackay JA, Zimmermann C, Mayer C, Howell D, Katz $\mathrm{M}$, et al. Clinician-patient communication: a systematic review. Support Care Cancer. 2009;17:627-44.

7. Fallowfield L, Jenkins V. Effective communication skills are the key to good cancer care. Eur J Cancer. 1999;35:1592-7.

8. Arksey H, O'Malley L. Scoping studies: towards a methodological framework. Int J Social Res Methodol. 2005;8:19-32.

9. Levac D, Colquhoun H, O'Brien KK, O'Brien KK. Scoping studies: advancing the methodology. Implement Sci. 2010;5:69. 1748-5908 (Electronic).

10. Peters MD, Godfrey CM, Khalil H, McInerney P, Parker D, Soares CB. Guidance for conducting systematic scoping reviews. Int J Evid Based Healthc. 2015;13:141-6. 1744-1609 (Electronic).

11. The Joanna Briggs Institute. The Joanna Briggs Institute Reviewers' Manual: 2015 edition/Supplement. Adelaide, Australia: The Joanna Briggs Institute, University of Adelaide; 2015.

12. Popay J, Roberts H, Sowden A, Petticrew M, Arai L, Rodgers M, et al. Guidance on the Conduct of Narrative Synthesis in Systematic Reviews: A Product from the ESRC Methods Programme. London: Institute for Health Research; 2006.

13. Petticrew M, Roberts H. Systematic reviews in the social sciences. Oxford, UK: Blackwell Publishing Ltd; 2006.

14. Moher D, Liberati A, Tetzlaff J, Altman DG, The Prisma Group. Preferred reporting items for systematic reviews and meta-analyses: the PRISMA statement. PLoS Med. 2009;6:e1000097.

15. Lobb EA, Butow PN, Barratt A, Meiser B, Gaff C, Young $\mathrm{MA}$, et al. Communication and information-giving in high-risk breast cancer consultations: influence on patient outcomes. Br J Cancer. 2004;90:321-7.

16. Metcalfe K, Liede A, Hoodfar E, Scott A, Foulkes W, Narod S. An evaluation of needs of female BRCA1 and BRCA2 carriers undergoing genetic counselling. J Med Genet. 2000;37:866-74.

17. Gleeson M, Meiser B, Barlow-Stewart K, Trainer AH, Tucker K, Watts KJ, et al. Communication and information needs of women diagnosed with ovarian cancer regarding treatment-focused genetic testing. Oncol Nurs Forum. 2013;40:275-83.

18. Meiser B. Getting to the point: what women newly diagnosed with breast cancer want to know about treatment-focused genetic testing. Oncol Nurs Forum. 2012;39:E101.

19. Jacobs C, Pichert G, Harris J, Tucker K, Michie S. Key messages for communicating information about BRCA1 and BRCA2 to women with breast or ovarian cancer: consensus across health professionals and service users. Psychooncology. 2017; 26:1818-24.

20. Butow PN, Lobb EA. Analyzing the process and content of genetic counseling in familial breast cancer consultations. J Genet Couns. 2004;13:403-24.

21. Lobb EA, Butow PN, Meiser B, Barratt A, Gaff C, Young MA, et al. Tailoring communication in consultations with women from high risk breast cancer families. Br J Cancer. 2002;87:502-8.

22. Pieterse $A H$, van Dulmen S, van Dijk S, Bensing JM, Ausems MG. Risk communication in completed series of breast cancer genetic counseling visits. Genet Med. 2006;8:688-96.

23. Randall J, Butow P, Kirk J, Tucker K. Psychological impact of genetic counselling and testing in women previously diagnosed with breast cancer. Intern Med J. 2001;31:397-405.

24. Vos J, Stiggelbout AM, Oosterwijk J, Gomez-Garcia E, Menko F, Collee JM, et al. A counselee-oriented perspective on risk communication in genetic counseling: explaining the inaccuracy of the counselees' risk perception shortly after BRCA1/2 test result disclosure. Genet Med. 2011;13:800-11.

25. Vos J, Gomez-Garcia E, Oosterwijk JC, Menko FH, Stoel RD, van Asperen CJ, et al. Opening the psychological black box in genetic counseling. The psychological impact of DNA testing is predicted by the counselees' perception, the medical impact by the 
pathogenic or uninformative BRCA1/2-result. Psychooncology. 2012;21:29-42.

26. Vos J, Oosterwijk JC, Gomez-Garcia E, Menko FH, Collee MJ, van Asperen CJ, et al. Exploring the short-term impact of DNAtesting in breast cancer patients: the counselees' perception matters, but the actual BRCA1/2 result does not. Patient Educ Couns. 2012;86:239-51.

27. Christie J. Cognitive and Psychological Impact of BRCA Genetic Counseling in Before and After Definitive Surgery Breast Cancer Patients. Ann Surg Oncol. 2012;19:4003-11.

28. Bredart A, Kop JL, De Pauw A, Caron O, Fajac A, Nogues C, et al. Effect on perceived control and psychological distress of genetic knowledge in women with breast cancer receiving a BRCA1/2 test result. Breast. 2016;31:121-7.

29. Scherr CL, Christie J, Vadaparampil ST. Breast cancer survivors' knowledge of hereditary breast and ovarian cancer following genetic counseling: an exploration of general and survivor-specific knowledge items. Public Health Genom. 2016;19:1-10.

30. Benusiglio PR, Di Maria M, Dorling L, Jouinot A, Poli A, Villebasse $\mathrm{S}$, et al. Hereditary breast and ovarian cancer: successful systematic implementation of a group approach to genetic counselling. Fam Cancer. 2017;16:51-6.

31. Mancini J, Nogues C, Adenis C, Berthet P, Bonadona V, Chompret A, et al. Impact of an information booklet on satisfaction and decision-making about BRCA genetic testing. Eur J Cancer. 2006;42:871-81.

32. Quinn VF, Meiser B, Kirk J, Tucker KM, Watts KJ, Rahman $\mathrm{B}$, et al. Streamlined genetic education is effective in preparing women newly diagnosed with breast cancer for decision making about treatment-focused genetic testing: a randomized controlled noninferiority trial. Genet Med. 2017;19:448-56.

33. Jacobs C, Dancyger C, Smith JA, Michie S. Accuracy of recall of information about a cancer-predisposing BRCA1/2 gene mutation among patients and relatives. Eur J Hum Genet. 2015;23:147-51.

34. Maheu $\mathrm{C}$, Thorne $\mathrm{S}$. Receiving inconclusive genetic test results: an interpretive description of the BRCA1/2 experience. Res Nurs Health. 2008;31:553-62.

35. Hallowell N, Foster C, Ardern-Jones A, Eeles R, Murday V, Watson M. Genetic testing for women previously diagnosed with breast/ovarian cancer: examining the impact of BRCA1 and BRCA2 mutation searching. Genet Test. 2002;6:79-87.

36. van Dijk S, van Asperen CJ, Jacobi CE, Vink GR, Tibben A, Breuning $\mathrm{MH}$, et al. Variants of uncertain clinical significance as a result of BRCA1/2 testing: impact of an ambiguous breast cancer risk message. Genet Test. 2004;8:235-9.

37. Vos J, Otten W, van Asperen C, Jansen A, Menko F, Tibben A. The counsellees' view of an unclassified variant in BRCA1/2: recall, interpretation, and impact on life. Psychooncology. 2008;17:822-30.

38. Vadaparampil ST, Quinn GP, Brzosowicz J, Miree CA. Experiences of genetic counseling for BRCA1/2 among recently diagnosed breast cancer patients: a qualitative inquiry. J Psychosoc Oncol. 2008;26:33-52.

39. van Roosmalen MS, Stalmeier PF, Verhoef LC, HoekstraWeebers JE, Oosterwijk JC, Hoogerbrugge N, et al. Impact of BRCA $1 / 2$ testing and disclosure of a positive test result on women affected and unaffected with breast or ovarian cancer. Am J Med Genet A. 2004;124A:346-55.

40. Pieterse AH, Ausems MG, Spreeuwenberg P, van Dulmen S. Longer-term influence of breast cancer genetic counseling on cognitions and distress: smaller benefits for affected versus unaffected women. Patient Educ Couns. 2011;85:425-31.

41. Augestad MT, Høberg-Vetti H, Bjorvatn C, Sekse RJT. Identifying needs: a qualitative study of women's experiences regarding rapid genetic testing for hereditary breast and ovarian cancer in the DNA BONus Study. J Genet Couns. 2017;26:182-9.
42. Vadaparampil ST, Quinn GP, Lee J-H, Malo T, Zhao X, Miree $\mathrm{C}$, et al. Satisfaction with physician recommendation for and information about genetic counseling among breast cancer patients. Breast J. 2011;17:79-82.

43. Sie AS, Spruijt L, van Zelst-Stams WA, Mensenkamp AR, Ligtenberg MJ, Brunner HG, et al. High satisfaction and low distress in breast cancer patients one year after BRCA-mutation testing without prior face-to-face genetic counseling. J Genet Couns. 2016;25:504-14.

44. Sie AS, Spruijt L, van Zelst-Stams WA, Mensenkamp AR, Ligtenberg MJ, Brunner HG, et al. DNA-testing for BRCA1/2 prior to genetic counselling in patients with breast cancer: design of an intervention study, DNA-direct. BMC Women's Health. 2012;12:12.

45. Roter D. The Genetic Counseling Video Project (GCVP): models of practice. Am J Med Genet C. 2006;142C:209.

46. Collins ED, Moore CP, Clay KF, Kearing SA, O'Connor AM, Llewellyn-Thomas HA, et al. Can women with early-stage breast cancer make an informed decision for mastectomy? J Clin Oncol. 2009;27:519-25. 1527-7755 (Electronic).

47. McInnes DK, Cleary PD, Stein KD, Ding L, Mehta CC, Ayanian JZ. Perceptions of cancer-related information among cancer survivors: a report from the American Cancer Society's Studies of Cancer Survivors. Cancer. 2008;113:1471-9.

48. Ellington L, Roter D, Dudley WN, Baty BJ, Upchurch R, Larson $\mathrm{S}$, et al. Communication analysis of BRCA1 genetic counseling. J Genet Couns. 2005;14:377-86.

49. Pieterse AH, Ausems MGEM, Van Dulmen AM, Beemer FA, Bensing JM. Initial cancer genetic counseling consultation: change in counselees' cognitions and anxiety, and association with addressing their needs and preferences. Am J Med Genet A. 2005; $137: 27-35$.

50. Aalfs CM, Oort FJ, de Haes HC, Leschot NJ, Smets EM. Counselor-counselee interaction in reproductive genetic counseling: Does a pregnancy in the counselee make a difference? Patient Educ Couns. 2006;60:80-90.

51. Michie S, Lester K, Pinto J, Marteau TM. Communicating risk information in genetic counseling: an observational study. Health Educ Behav. 2005;32:589-98.

52. Meiser B. Psychological impact of genetic testing for cancer susceptibility: an update of the literature. Psychooncology. 2005;14:1060-74.

53. Albada A, van Dulmen S, Lindhout D, Bensing JM, Ausems MG. A pre-visit tailored website enhances counselees' realistic expectations and knowledge and fulfils information needs for breast cancer genetic counselling. Fam Cancer. 2012;11:85-95.

54. Kelly K, Leventhal H, Marvin M, Toppmeyer D, Baran J, Schwalb M. Cancer genetics knowledge and beliefs and receipt of results in Ashkenazi Jewish individuals receiving counseling for BRCA1/2 mutations. Cancer Control. 2004;11:236-44.

55. Butow PN, Lobb EA, Meiser B, Barratt A, Tucker KM. Psychological outcomes and risk perception after genetic testing and counselling in breast cancer: a systematic review. Med J Aust. 2003;178:77-81.

56. Smerecnik CMR, Mesters I, Verweij E, De Vries NK, De Vries H. A systematic review of the impact of genetic counseling on risk perception accuracy. J Genet Couns. 2009;18:217-28.

57. Hallowell N, Foster C, Eeles R, Ardern-Jones A, Watson M. Accommodating risk: Responses to BRCA1/2 genetic testing of women who have had cancer. Soc Sci Med. 2004;59: 553-65.

58. Gallo AM, Angst DB, Knafl KA. Disclosure of genetic information within families. Am J Nurs. 2009;109:65-9.

59. Claes E, Evers-Kiebooms G, Boogaerts A, Decruyenaere M, Denayer L, Legius E. Communication with close and distant relatives in the context of genetic testing for hereditary breast and 
ovarian cancer in cancer patients. Am J Med Genet A. 2003;116A:11-9.

60. Eccles BK, Copson E, Maishman T, Abraham JE, Eccles DM. Understanding of BRCA VUS genetic results by breast cancer specialists. BMC Cancer. 2015;15:936.

61. Mendes AF, Santos TA, Sousa L. Experiencing genetic counselling for hereditary cancers: The client's perspective. Eur J Cancer Care (Engl). 2011;20:204-11.

62. Farrelly A, White V, Meiser B, Jefford M, Young M, Ieropoli S, et al. Unmet support needs and distress among women with a BRCA1/2 mutation. Fam Cancer. 2013;12:509-18.

63. Bonadona V, Saltel P, Desseigne F, Mignotte H, Saurin J-C, Wang Q, et al. Cancer Patients Who Experienced Diagnostic Genetic Testing for Cancer Susceptibility. Cancer Epidemiol Biomark Prev. 2002;11:97.

64. Ardern-Jones A, Kenen R, Eeles R. Too much, too soon? Patients and health professionals' views concerning the impact of genetic testing at the time of breast cancer diagnosis in women under the age of 40. Eur J Cancer Care (Engl). 2005;14:272-81.
65. Wevers MR, Aaronson NK, Bleiker EMA, Hahn DEE, Brouwer $\mathrm{T}$, van Dalen $\mathrm{T}$, et al. Rapid genetic counseling and testing in newly diagnosed breast cancer: Patients' and health professionals' attitudes, experiences, and evaluation of effects on treatment decision making. J Surg Oncol. 2017;116:1029-39.

66. Zilliacus E. Are we being overly cautious? A qualitative inquiry into the experiences and perceptions of treatment-focused germline BRCA genetic testing amongst women recently diagnosed with breast cancer. Support Care Cancer. 2012;20:2949-58.

67. Calzone KA, Prindiville SA, Jourkiv O, Jenkins J, DeCarvalho $\mathrm{M}$, Wallerstedt DB, et al. Randomized comparison of group versus individual genetic education and counseling for familial breast and/or ovarian cancer. J Clin Oncol. 2005; 23:3455-64.

68. Bradbury A, Patrick-Miller L, Harris D, Stevens E, Egleston B, Smith K, et al. Utilizing Remote Real-Time Videoconferencing to Expand Access to Cancer Genetic Services in Community Practices: A Multicenter Feasibility Study. J Med Internet Res. 2016;18:e23. 